to rise up a strip of paper and the paper afterwards developed with Nitroso- $R$ salt, it can be shown that cobalt is adsorbed on the lower part of the strip, the oil being denuded of drier. Acid papers adsorb the cobalt more strongly. The adsorption is irreversible and probably involves the hydrolysis of the cobalt soap or an ion exchange process between the soap and the cellulose. The rate of adsorption is slow, and the amount adsorbed at any given time is proportional to the square root of the time.

Arrangements are being made for the publication in full of the papers read and the ensuing discussions.

G. L. RIDDELL

\section{CORROSION OF BURIED METALS}

A

SYMPOSIUM on the corrosion of buried metals was held jointly by the Iron and Steel Institute, the British Iron and Steel Research Association and the Corrosion Group of the Society of Chemical Industry in London on December 12. Sir Charles Goodeve was in the chair, and about three hundred people attended. Preprints of the papers under discussion were circulated before the meeting.

In his opening remarks, Sir Charles Goodeve said that modern communities are dependent on a number of services, of which the chief are water, gas, electricity and sewage, and the corrosion of underground pipelines or cables conveying these is a problem of great magnitude. He referred to the report of the Ministry of Health Departmental Committee on the Deteriora. tion of Cast Iron and Spun Iron Pipes published in 1950. This report stressed the need for further research, and the work had been entrusted to the British Iron and Steel Research Association's SubCommittee on the Corrosion of Buried Metals formed in March 1950. Represented on this Sub-Committee were manufacturers and users of ferrous and nonferrous materials, gas and water engineers and others, so that a very satisfactory representation and co-ordination of the interests concerned had been achieved. One of the earliest actions of the Sub-Committee was to make plans for the present symposium.

In the first session the papers discussed were "Tests on the Corrosion of Buried Iron and Steel Pipes" by J. C. Hudson and G. P. Acock, and "Investigations on Underground Corrosion" by K. R. Butlin, W. H. J. Vernon and L. C. Whiskin. In introducing the first paper, Dr. Hudson gave a brief survey of the events leading to the research, and $\mathrm{Mr}$. Acock described the interim results contained in the paper. The second paper was introduced by Dr. Vernon.

Dr. W. F. Higgins, opering the discussion, questioned the value of tests using short lengths of pipe, and pointed out that variations in the composition of the soil along the length of a pipe could, by a concentration-cell effect, lead to corrosion at certain places. Such effects were not reproduced in the tests described, which could not, therefore, purport to indicate the behaviour of pipe-lines. Mr. W. G. Waite supported this contention and mentioned a number of other ways in which the test conditions were different from those of practice. He felt that additional useful information would have been provided by measurements of the loss of mechanical properties of the materials buried, and determinations of the con- ductivities of soil waters. Mr. N. J. Pugh was also doubtful about the value of tests on short lengths. He mentioned several factors occurring in practice which could affect the course of corrosion, particularly the setting up of internal stresses by pressure fluctuations in water mains. Sir Charles Goodeve afterwards commented on these criticisms of the use of small specimens and pointed out that similar problems arise in many branches of scientific work. It is a fact, he said, that the accuracy of measurement falls off as the scale of the experiment increases, until on the full scale the accuracy is usually too low to give useful results owing to the presence of uncontrolled variables. Furthermore, the cost of experiments rises sharply as the scale increases. A compromise is desirable where accuracy of measurement, correspondence to practical conditions and cost are all at reasonable levels.

A number of speakers discussed the merits and disadvantages of various protective coatings or schemes. Mr. Hussey pointed out that certain soils are not corrosive, as shown by the condition of excavated museum specimens, and thought that certain elay-chalk mixtures might be used to give protection. Mr. Warner described how 6 in. of puddled clay around buried tanks used for storing petroleum products had kept the tanks in relatively good condition for more than sixty years, connecting pipe-lines having been much more severely corroded. Mr. E. W. Rawlings said that latex cement, which can be applied by spraying, has been successfully used.

Dr. F. Wormwell gave some details of work in progress at the Chemical Research Laboratory, Teddington. Electrochemical measurements are being made to throw more light on the mechanism of microbiological corrosion. It has been found that this type of attack can be prevented by cathodic protection. Earlier Mr. Waite had expressed the view that perhaps too much emphasis had recently been given to the part played by bacteria in corrosion, and in the course of his reply to the discussion Dr. Vernon said that, he and his colleagues have taken every opportunity of pointing out that microbiological corrosion is not basically different from electrochemical corrosion, of which it is merely a special type. He stressed that, contrary to the views expressed by one or two speakers, a noteworthy feature of soil corrosion research is the close co-operation that has been established between research workers and users. Mr. L. C. Whiskin, chairman of the Sub-Committee on Corrosion of Buried Metals, referred briefly to the current activities of the Sub-Committee.

In the second session the two papers discussed were "Cathodic Protection" by K. A. Spencer and "Cathodic Protection of Buried Metal Structures" by R. de Brouwer. Mr. Spencer introduced both his own paper and that by M. de Brouwer, who was unfortunately prevented from attending. During the course of his introduction, Mr. Spencer showed a short film on the laying of an oil pipe-line in Scotland, illustrating the installation of magnesium anodes.

Several speakers stressed the low cost of cathodic protection and its high efficiency in preventing corrosion. Mr. C. W. Marshall mentioned successful applications of the method in Belgium and Holland, and Dr. A. J. Maurin described its application in France. $\mathrm{He}$ distinguished between specific aggressivity and apparent aggressivity over the length of a pipe-line, and said that nomograms have been constructed for calculating specific aggressivity from certain soil 
characteristics. Cathodic protection is being applied to some $600 \mathrm{~km}$. of new gas mains every year. $\mathrm{Mr}$. C. W. N. McGowan described a cathodic protection installation for jetty piling in the Persian Gulf, and Mr. H. C. S. Hayes gave details of the experience of the General Post Office. Corrosion of lead-sheathed cables in earthenware ducts is widespread, and although this can be prevented by wrapping with impregnated hessian tape, this solution to the problem is not attractive owing to its expense and the space taken in the duct. Preliminary tests of cathodic protection have been successful.

A number of speakers discussed the techniques of measuring pipe/soil potentials using copper/copper sulphate reference electrodes, and the significance of the results obtained. Mr. J. H. Gosden showed how such measurements had facilitated the diagnosis of corrosion of lead-covered cables which had been caused both by stray currents from an adjacent traction system and by electrolytic action. Mr. Spencer briefly replied to the discussion.

The third session was devoted to the following papers: "Corrosion of Buried Copper and Forrous Strips in Natural and Salted Soils", by the British Electrical and Allied Industries Research Association, and "Tests on the Corrosion of Buried Alumin. ium, Copper and Lead", by P. T. Gilbert and F. C. Porter. The first paper was introduced by Dr. G. Mole and the second by Mr. Porter.

Dr. F. A. Champion considered the results in the first paper could have been better presented in the form of a simple plot of corrosion against time. He agreed that the eifect of salting, as sometimes carried out when earthing plates are installed, is largely confined to increasing corrosion in the early life. Regarding the second paper, he considered that the presence of relatively large amounts of chloride and sulphate is not in itself an adequate explanation of the corrosion of aluminium, and suggested that mol' $\theta$ attention should be paid to the question of the copper content of the soil waters. He referred briefly to the results of some tests carried out by his colleagues, which showed that a protective scheme incorporating barium chromate as inhibitor gave promising results on aluminium specimens buried for two years in cinders.

Mr. Gosden drew the general conclusion that bare copper is normally adequately resistant to soil corrosion, that aluminium should not be buried without a good protective coating and that the position of lead is intermediate. He gave details of the experience of the British Electricity Authority with 130,000 miles of lead-sheathed cable. In 1949, 106 faults occurred, of which sixty-three were due to electrolytic action and twenty-seven to chemical action of various types. Mr. J. B. Cotton mentioned the danger of accelerated attack at defects in a tin coating on copper.

Mr. E. A. G. Liddiard thought clad aluminium ulloys have possibilities. In reply to his query about experiments to follow corrosion by change in electrical resistance, Dr. Hudson said that plans for such experiments had been well advanced but circumstances had necessitated their abandonment. $\mathrm{Mr}$. R. L. Davies described some experiments which suggested that aluminium could corrode rapidly in anaerobic conditions.

Dr. Mole and Dr. Gilbert replied briefly to the discussion.

The papers on which the discussion was based and a full account of the discussion will be published in due course by the Iron and Steel Institute.

\section{NATIONAL RESEARCH COUNCIL OF CANADA}

\author{
ANNUAL REPORT FOR 1950-51
}

$T$

HE thirty-fourth annual report of the National Research Council for 1950-51* includes the report of the president, Dr. C. J. Mackenzie, the Financial Statement and a financial statement and summary of the operations of Canadian Patents and Developments, Ltd., for the year ended March 31, 1951.

In the Division of Applied Biology the macromolecule laboratory is investigating the size, shape and charge of several carbohydrate extracts of marine algæ, upon which their industrial value depends, and the microbial decomposition of cellulose is also being studied with the view of the utilization of industrial wastes. In the plant science section the mechanism of photosynthesis and particularly the transformation of absorbed light energy into chemical energy or reducing power is being investigated, while the industrial fermentations group has found that Pseudomonas hydrophila is superior to all other organisms for the production of $2: 3$-butylene glycol from sulphite waste liquor or from beet molasses. Re-designing the overhead bunkers in the standard railway refrigerator-car by extending the cooling surface with fins and improving the air circulation has resulted in a reduction of the air temperature in the car by $4.5^{\circ} \mathrm{F}$.

Work on marine products has been concluded, and the project will be transferred to the Maritime Regional Laboratory. Conditions for extracting alginates from Canadian seaweeds were established, and soluble chitosans obtained by deacetylating chitin from lobster shells. In the Prairie Regional Laboratory, Saskatoon, work was continued on the fermentation of sugars by the corn-smut fungus, Ustilago zece, and studies were continued on the production of glycerol with Bacillus subtilis to establish the conditions giving rapid fermentation with consistently high yields from a starch substrate. The possibility of using mould enzymes for solubilizing or modifying materials which contain protein is being studied as well as the formation of lignin in wheat plants, and work was continued on spray-drying wheat gluten.

In the Division of Chemistry a specially designed ultrasonic interferometer has been used to measure the velocity and absorption of sound in the region of the liquid-gas critical temperature. While the photoconductivity of anthracene was confirmed, no photoconductivity was observed for octadecane. More information has been obtained on the shape factor of the individual particles and agglomerates in thixotropic suspensions from the rheological properties of the systems as a whole. Elucidation of the structure of the lupin alkaloid thermopsine has supplied the key to the structure of two new alkaloids, $\alpha$-isosparteine and $\alpha$-isolupanine, while progress is reported in the interpretation of infra-red spectra of fatty acids. In applied chemistry the pilot-plant work on the recovery of oil from Alberta bituminous sands has continued, and a combination of water separation with flash distillation in a fluidized bed appears likely to provide an economic process for the recovery of oil from such sands. Besides investigations on the causes of normal corrosion in domestic hot-water heaters and the cooling-systems of internal com-

* Thirty-fourth Annual Report of the National Research Council of Canada, 1950-51. (N.R.C. No. 2463.) Pp. 43. (Ottawa: King's Printer, 1951.) 